\title{
Ethnomedicinal Studies on Amritsar District (Punjab), India
}

\author{
Preeti Singh* \\ Researcher, Trans-Disciplinary University, India
}

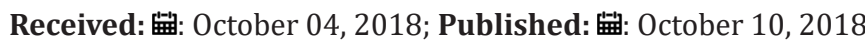

*Corresponding author: Preeti Singh, Researcher, Trans-Disciplinary University, Bengaluru, Karnataka, India

\begin{abstract}
The general population in and around zone of Amritsar region has been utilizing various herbs for remedial reason since time immemorial. Villagers predominantly rely upon the herbs for all maladies. They know about the plant solutions for regular afflictions like the runs, jaundice, ailment, dyspepsia, asthma, diabetes, looseness of the bowels, sickness and skin maladies. Pharmacological and clinical characteristics will help in the affirmation of the adequacy of the announced herbs. The utilization of the announced plant species were gathered from the territorial individuals, who utilize them as custom. In this way, it isn't prudent to utilize them without counseling an accomplished ayurvedic doctor. For the advantage of the group the recorded plant species ought to be dealt with and furthermore steps be taken for preservation and also development of these plant species.
\end{abstract}

Keywords: Ethnobotanical; Restorative Herbs

\section{Introduction}

India is the biggest maker of restorative herbs and is properly called as The Professional flowerbed of the world Utilization of plants as a wellspring of solutions has been acquired and is an essential segment of social insurance framework in India. The enthusiasm for customary prescriptions is developing exponentially in broad daylight, scholastic and government hovers because of the expanded occurrences of the antagonistic medication responses and the financial weight of the cutting-edge arrangement of medicine Individuals living in towns and inborn territories are utilizing indigenous plants as a wellspring of solutions for a long time. Therapeutic plants are living assets, modest if abused and manageable if utilized with care and knowledge. Their manageability is fundamental as it is one of the world's most established medicinal conventions, an extremely valuable heritage of the Indians-"The Ayurveda". A huge number of provincial families utilize restorative plants in a self-improvement mode [1]. The experts of the Indian frameworks of pharmaceutical, in the oral and classified streams, utilize therapeutic plants in preventive, primitive and therapeutic applications. Amid the most recent couple of decades, there has been an expanding enthusiasm for the investigation of therapeutic plants and their conventional uses in various parts of the world. This learning depends on individual encounters of the concerned people and the elderly individuals of the families in our general public. The Data is passed on orally from age to age. The Indian arrangement of prescription is tremendous to such a degree, to the point that it requires legitimate documentation and research on the current vegetation time to time.
Remembering the significance of therapeutic plants, been utilized as a part of different Ayurvedic arrangements, in and around region Amritsar, in different ayurvedic drug stores exhibit here and the crude meds been sold here from the nearby pharmaceutical market named majeeth mandi, the correct documentation has been started as my subject for the present investigation. Since Amritsar is a fare center point for restorative plants, countless plants being sent out from the area [2]. Thus, some therapeutically critical plant species are disposing of at a quick speed, so the region needs appropriate assurance for the protection and survival of bioresearches. There is a critical need to record the rundown of restorative plants and their utilization for the accommodation of nearby individuals, with the goal that these plants can be ensured through the preservation programs.

\section{Materials and Methods}

\section{The Study Area}

Amritsar is one of the fringe locale lying in the North-West boondocks of the Indian territory of Punjab. The city is situated at 310.63 N740.87E. It has a normal height of $234 \mathrm{~m} .(768 \mathrm{ft}$.) and $27 \mathrm{~km}$. from the global outskirt amongst India and Pakistan. The Amritsar region encounters extremes of climatic conditions i.e. summers are exceptionally sweltering (max.49.50c) and winters are extremely chilly (Min - 4oc). A yearly normal precipitation of around $541.9 \mathrm{~mm}$ has been recorded here. Punjab isn't blessed in having a substantial woods cover. The parched and semiarid atmosphere of the state isn't positive for the development of backwoods. In any case, the 
woods region of the Punjab is 9278 sq. m., of which 1916 sq. m. is saved and 4909 sq. m.is secured.

Out of Punjab, the Amritsar dist. has increased greatest timberland cover in the last 2 yrs [3]. The biennial India condition of woods report,2011, reveals that Amritsar, which is a nonbackwoods locale, has picked up 16 sq. km of backwoods cover.

The zone is having characteristic fields with huge woods front of Shisham (Dalbergia sissoo) and Kikar (Acacia nilotica), Ber (Ziypus jujoba) and so on. Keeping in mind the end goal to randomize information accumulation and examining, the whole locale was isolated into four zones viz. North-East, North-West, South-East and South-West.

Six towns namely Raja Sansi, Khasa, Chheharta, Chabal Kalan, Jandiala and Majitha were chosen for testing and information accumulation.

\section{Source Population and Study Population}

The source populace for the present investigation contained the tenants of the Amritsar distt. Also, the previously mentioned towns and villas around these towns. Notwithstanding, the examination populace for information accumulation about the therapeutic plant riches was self-reviews and the data assembled from the elderly people about self-medicine for treating minor illnesses utilizing family unit arrangements of neighborhood herbs. Around 10 people (5 guys and 5 females) from every one of the six towns and 2-3 conventional healers were reached for gathering the information.

\section{Study Design}

The investigation was intended to cover the two unique yet reciprocal perspectives i.e. Meetings and introduction of the therapeutic plants.

\section{Interviews and Data Collection}

The people of the previously mentioned classes from the examination zone were met with respect to the data about the plants utilized regularly, the nearby/vernacular names of the therapeutic plants, part utilized, methods of planning, strategies for organization/application and the infirmities/ailments cured were obtained.

At times the dried or crisp plants were gotten and related to the assistance of sources [4].

\section{Sampling and Collection of Material}

They chose territory was gone by for test accumulation of the restorative plants amid various periods of the year to guarantee the total documentation of the therapeutic verdure (Feb.2015Aug.2016) [5]. The standard strategies for drying, mounting and saving of plant examples were utilized to get ready herbarium sheets. The gathered plants were distinguished up to species level with the assistance of the herbarium kept up by Amritsar and Deptt. of Organic \&Environmental sciences, Master Nanak Dev College, Amritsar.

\section{Results and Discussion}

(Table 1)
Table 1: List of Medicinal Plants.

\begin{tabular}{|c|c|c|c|}
\hline Sl.No. & Plant Name & Botanical name & Type of Plant \\
\hline 1. & Arjuna & Terminalia arjuna & Tree \\
\hline 2. & Aragvadh & Cassia fistula & Tree \\
\hline 3. & Amra & Mangifera indica & Tree \\
\hline 4. & Arka & Calatropis procera & Herb \\
\hline 5. & Amalaki & Emblica officinalis & Tree \\
\hline 6. & Ashvagandha & Withania somnifera & Shrub \\
\hline 7. & Ashvath & Ficus religiosa & Tree \\
\hline 8. & Apamarg & Achyranthus aspera & Herb \\
\hline 9. & Ashvagol & Plantago ovata & Herb \\
\hline 10. & Ardaraka & Zingiber officinale & Herb \\
\hline 11. & Anjeer & Ficus carica & Tree \\
\hline 12. & Ajmoda & Carum roxburghii & Herb \\
\hline 13. & Atibala & Abutilon indicum & Shrub \\
\hline 14. & Akashvalli & Cuscuta reflex & Climber \\
\hline 15. & Alsi & Linum usitatissimum & Herb \\
\hline 16. & Arishtrak & Sapindus saponeria & Tree \\
\hline 17. & Bibhitak & Terminalia bellirica & Tree \\
\hline 18. & Bakul & Mimusiops elengi & Tree \\
\hline 19. & Bhringraj & Eclipta alba & Herb \\
\hline 20. & Bimbi & Coccinia grandis & Climber \\
\hline 21. & Brahmi & Centalla asiatica & Herb \\
\hline 22. & Balamkheera & Kigelia pinnata & Tree \\
\hline 23. & Babool & Acacia arabica & Tree \\
\hline 24. & Bilva & Aegle marmelos & Tree \\
\hline 25. & Bhoomyamalaki & Phyllanthus urinaria & Herb \\
\hline 26. & Bhanga & Cannabis sativa & Herb \\
\hline 27. & Badriphal & Zizypus jujoba & Tree \\
\hline 28. & Changeri & Oxalis corniculata & Herb \\
\hline 29. & Chitrak & Plumbago zeylanicum & Herb \\
\hline 30. & Chakramard & Cassia tora & Herb \\
\hline 31. & Chandershoor & Lepidium sativum & Herb \\
\hline 32. & Chincha & Tamarindus indicus & Tree \\
\hline 33. & Chukra & Chukrasia tabularis & Tree \\
\hline 34. & Cheeku & Achrus sapota & Tree \\
\hline 35. & Chaulai & Amaranthus polygamus & Herb \\
\hline 36. & Chanak & Cicer arietinum & Herb \\
\hline 37. & Draksha & Vitis vinifera & Climber \\
\hline 38. & Dugdhika & Euphorbia thymifolia & Herb \\
\hline 39. & Dadima & Punica granatum & Tree \\
\hline 40. & Dhatura & Dhatura alba & Shrub \\
\hline 41. & Durva & Cynodon dactylon & Herb \\
\hline 42. & Dhanyak & Coriandrum sativum & Herb \\
\hline 43. & Dhamasa & Fagonia cretica & Herb \\
\hline 44. & Erand & Ricinus communis & Shrub \\
\hline 45. & Erand karkati & Carica papaya & Tree \\
\hline 46. & Gunja & Abrus prectorius & Climber \\
\hline 47. & Guduchi & Tinospora cardifolia & Climber \\
\hline
\end{tabular}




\begin{tabular}{|c|c|c|c|c|c|c|c|}
\hline 48. & Ghritkumari & Aloe barbendensis & Herb & 95. & Nirgundi & Vitex negundo & Shrub \\
\hline 49. & Godhum & Triticum aestivum & Herb & 96. & Patol & Tricosanthes dioica & Climber \\
\hline 50. & Gokshur & Tribulis terrestris & Herb & 97. & Patrang & Caesalpinia sappan & Shrub \\
\hline 51. & Garjur & Daucus carota & Herb & 98. & Patha & Caesamplos pariera & Climber \\
\hline 52. & Gudhal & Hibiscus rosa sinensis & Shrub & 99. & Palandu & Allium сера & Herb \\
\hline 53. & Genda & Tagetes erecta & Herb & 100. & Putiha & Mentha spicata & Herb \\
\hline 54. & Haridra & Curcuma longa & Herb & 101. & Parushak & Grewia subinaequalis & Shrub \\
\hline 55. & Haritaki & Terminalia chebula & Tree & 102. & Palash & Butea monosperma & Tree \\
\hline 56. & Harsingar & Nyctnthes arbortristis & Shrub & 103. & Parnabeej & Bryophylum pinnatum & Herb \\
\hline 57. & Ikshu & Saccharum officinarum & Herb & 104. & Pippermint & Mentha Piperata & Herb \\
\hline 58. & Jambu & Syzygium cumini & Tree & 105. & Pipali & Piper longum & Climber \\
\hline 59. & Jati & Jasminum officinale & Climber & 106. & Peevari & Abroma augusta & Shrub \\
\hline 60. & Karvir rakta & Nerium indicum & Shrub & 107. & Putranjeevak & Putranjiva Roxburghii. & Tree \\
\hline 61. & Karvir peet & Thevetia nerifolia & Tree & 108 & Rason & Allium sativum & Herb \\
\hline 62. & Kadali & Musa paradisiaca & Tree & 109. & Rakta erand & Jatropha gossypifolia & Herb \\
\hline 63. & Karpas & Gossypium herbaceum & Shrub & 110. & Raasna & Pluchea lanceolata & Herb \\
\hline 64. & Karanj & Caesalpinia crista & Shrub & 111. & Shalmali & Bombax ceiba & Tree \\
\hline 65. & Kamini & Murraya panniculata & Shrub & 112. & Shirish & Albizzia lebbeck & Tree \\
\hline 66. & Karmard & Carissa congesta & Shrub & 113. & Shatavari & Asparagus racemosus & Climber \\
\hline 67. & Karvellak & Momordica charantia & Climber & 114. & Shleshmatak & Cordia dichotoma & Tree \\
\hline 68. & Kanchanar & Bauhinia varigata & Tree & 115. & Sanuhi & Euphorbia neriifolia & Shrub \\
\hline 69. & Kaashtdaaru & Polyalthia longifolia & Tree & 116. & Safeda & Eucalyptus globuluss & Tree \\
\hline 70. & Kamal & Nelumbo nucifera & Herb & 117. & Saptaparna & Alstonia scholaris & Tree \\
\hline 71. & Kadamb & Anthocephalus indicus & Tree & 118. & Sudershan & Crinum latifolium & Herb \\
\hline 72. & Kasmard & Cassia occidentalis & Herb & 119. & Sagon & Tectona grandis & Tree \\
\hline 73. & Khatmi & Althea officinalis & Herb & 120. & Sarshap & Brassica compestris & Herb \\
\hline 74. & Koshataki & Luffa actangula & Climber & 121. & Shobhanjan & Moringa oleifera & Tree \\
\hline 75. & Kushmand & Benincasa hispida & Climber & 122. & Snay & Cassia augustifolia & Herb \\
\hline 76. & Lonika & Portulaca oleraceae & Herb & 123. & Sadabahar & Vinca rosea & Herb \\
\hline 77. & Lanka & Capsicum annum & Herb & 124. & Saunf & Foeniculum vulgare & Herb \\
\hline 78. & Lemongrass & Cymbopogon citrates & Herb & 125. & Shinshpa & Dalbergia sissoo & Tree \\
\hline 79. & Lajjalu & Mimosa pudica & Herb & 126. & Shahtoot & Morus indica & Tree \\
\hline 80. & Mahanimb & Melia azardirachta & Tree & 127. & Suryuamukhi & Helianthus annus & Herb \\
\hline 81. & Makoy & Solanum nigrum & Herb & 128. & Sairayak & Barleria prionitis & Shrub \\
\hline 82. & Motha & Cyprus rotundus & Herb & 129. & Sarpagandha & Rauwolfia serpentina & Herb \\
\hline 83. & Madyantika & Lawsonia intermis & Shrub & 130. & Til & Sesamum orientale & Herb \\
\hline 84. & Meetha neem & Murraya koenigi & Tree & 131. & Tumbi & Lagenaria siceraria & Climber \\
\hline 85. & Mayurpankh & Thuja compacta & Shrub & 132. & Taruni & Rosea centifolia & Shrub \\
\hline 86. & Malti & Jasminum sambac & Shrub & 133. & Tulsi shwet & Ocimum sanctum & Herb \\
\hline 87. & Moolak & Raphanus sativus & Herb & 134. & Tulsi ram & Ocimum grattisimum & Herb \\
\hline 88. & Mishreya & Foeniculum vulgare & Herb & 135. & Udumbar & Ficus glomerata & Tree \\
\hline \multirow{2}{*}{89.} & \multirow{2}{*}{ Methika } & \multirow{2}{*}{$\begin{array}{c}\text { Trigonella foenum- } \\
\text { graecum }\end{array}$} & \multirow{2}{*}{ Herb } & 136. & Vat & Ficus bengalensis & Tree \\
\hline & & & & 137. & Vasa & Adhatoda vasica & Herb \\
\hline 90. & Munditak & Sphaeranthus indicus & Herb & 138. & Vansh & Bambusa bombos & Shrub \\
\hline 91. & Masur & Lens culinaris & Herb & 139. & Vanplandu & Urginia indica & Herb \\
\hline 92. & Nimba & Azadirachta indica & Tree & 140. & Varuna & Crateva nervula & Tree \\
\hline 93. & Nagdaman & $\begin{array}{l}\text { Sansevieria } \\
\text { roxburghiana }\end{array}$ & Herb & 141. & Yuva & Haredim vulgare & Herb \\
\hline 94. & Nimbuk & Citrus limon & Tree & 142. & Yashtimadhu & Glycirrhiza glabra & Herb \\
\hline
\end{tabular}




\section{Conclusion}

The overall publics of in and around domain of Amritsar district have been using different herbs for accommodating reason since time immemorial. Villagers essentially depend upon the herbs for all ailments. They think about the plant answers for essential pains like free insides jaundice, solidness, dyspepsia, asthma, diabetes, detachment of the entrails, and contamination and skin sicknesses. Pharmacological and clinical attributes will help in the assertion of the ampleness of the declared herbs. The use of the declared plant species were accumulated from the commonplace people, who use them as custom. In this way, it isn't fitting to use them without guiding an achieved ayurvedic specialist. For the upside of the system the recorded plant species should be managed

ISSN: 2574-1241

DOI: $10.26717 / B J S T R .2018 .09 .001873$

Preeti Singh. Biomed J Sci \& Tech Res

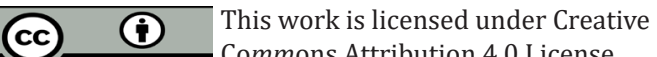

Submission Link: https://biomedres.us/submit-manuscript.php and moreover steps be taken for assurance and furthermore improvement of these plant species.

\section{References}

1. Anonymous $(1950,1952,1956,1959,1962,1965,1962,1965,1972,1985,1$ $986,1992,2000,2002,2003)$.

2. Aitchison JET (1869) A Catalogue of the plants of the Punjab and Sindh. London.

3. Aitchison JET (1868) Flora of Hoshiarpur District of Punjab 11: 17-22.

4. Aitchison JET (1864) On the vegetation of the Jhelum District of the Punjab. J Asiat J Linn Soc [Bot]33: 290-320.

5. Aitchison JET (1864) Flora of the Jhelum District of the Punjab J Linn Soc [Bot]. London 8: 55-75.

$\begin{array}{ll}\text { BIOMEDICAL } & \text { Assets of Publishing with us } \\ \text { RESEARCHES } & \text { - Global archiving of articles } \\ \text { - Immediate, unrestricted online access } & \text { - Rigorous Peer Review Process } \\ & \text { - Authors Retain Copyrights }\end{array}$

